Marcin Łysko

\title{
Kara pracy poprawczej w orzecznictwie karno-administracyjnym Polski Ludowej
}

Keywords: Correctional labor, Petty offences

\section{Summary}

The penalty of corrective labor was introduced into Polish system of jurisdiction in petty offences cases in 1951 and it replaced the penalty of arrest. The essence of this penalty consisted in the duty to work in appointed place and part of salary was confiscated. The idea was that this penalty will have educational influence on the sentenced person and it will bring him up to live in the socialist society. However, the practice was different. In fact the state was only confiscating a part of salary, so this punishment was rather a kind of a fine in instalments. The penalty was inefficient especially in hooligan nature cases, and it was gradually replaced by the penalty of arrest. In December 1958 the correctional labor penalty was abolished and the boards judging petty offences (not courts) were empowered to decree the punishment of arrest. It was a retreat from the earlier concepts of the educational role of this jurisdiction. The modified version of this penalty exists till now in the petty offences' code from 1971. It is known as "penalty of restricted liberty". This penalty can be replaced now by penalty either of arrest or fine.

\section{Podstawowe założenia orzecznictwa karno-administracyjnego Polski Ludowej}

Przemiany w prawie Polski Ludowej przełomu lat czterdziestych i pięćdziesiątych nie pozostały bez wpływu na orzecznictwo karno-administracyjne, które zostało ukształtowane w duchu socjalistycznym przy wykorzystaniu wzorów i doświadczeń Związku Radzieckiego. Socjalistyczne orzecznictwo karno-administracyjne miało stanowić alternatywę dla rozwiązań pochodzących z okresu 
międzywojennego, przejętych przez pragnących zachować pozory legalności sprawowanej władzy komunistów. Przedwojenny model orzecznictwa w sprawach o wykroczenia oparty był na rozporządzeniu Prezydenta RP z 22 marca 1928 r. o postępowaniu karno-administracyjnym ${ }^{1}$. Rozporządzenie przekazywało do kompetencji organów administracji orzekanie w sprawach o wykroczenia zagrożone karą nie wyższą niż grzywna do 3000 złotych i 3 miesiące aresztu. Kara administracyjna stawała się prawomocna i mogła być wykonana pod warunkiem nieskorzystania przez ukaranego $\mathrm{z}$ możliwości przekazania sprawy sądowi, co podkreślało zastępczy charakter orzecznictwa karno-administracyjnego $^{2}$. Polskie rozwiązania cechowało przyznanie organom administracyjnym wyłączności karania w sprawach o wykroczenia w pierwszej instancji, co argumentowano względami celowości, a zwłaszcza prostoty i szybkości postępowania administracyjnego ${ }^{3}$. Przedwojenny system orzecznictwa karno-administracyjnego sprawdził się w praktyce, gdyż dając administracji możliwość szybkiej reakcji na popełnione wykroczenia, wymagał od niej ścisłego przestrzegania prawa pod sankcją skierowania sprawy na drogę postępowania sądowego ${ }^{4}$.

Pomimo swoich niewątpliwych zalet, przedwojenny model orzecznictwa karno-administracyjnego tracił stopniowo rację bytu wraz z umacnianiem się pozycji komunistów w powojennej Polsce. Celem nowej władzy było zbudowanie ustroju socjalistycznego na wzór radziecki, co wymagało wprowadzenia gruntownych przemian politycznych, gospodarczych i społecznych. Proces sowietyzacji Polski przybrał na sile od końca 1948 r. wraz z przejęciem kierownictwa partyjnego przez w pełni posłuszną Moskwie ekipę Bolesława Bieruta, osiągając swoje apogeum w pierwszej połowie lat pięćdziesiątych, okresie tzw. polskiego stalinizmu. Aktywną rolę w tym procesie miała odgrywać administracja państwowa, której powierzono zadanie planowej przebudowy i kształtowania stosunków społecznych i gospodarczych w duchu socjalistycznym. Przejmując na swoje barki ciężar organizowania życia społecznego i gospodarczego, w tym obowiązek zaspokajania podstawowych potrzeb obywateli, administracja miała realizować funkcję organizatorską i kulturalno-wychowawczą państwa socjalistycznego. Na tle nowych funkcji administracji dotychczasowe metody działania w postaci aktów nakazu i zakazu, poparte w razie potrzeby przymusem administracyjnym, oceniono jako niewystarczające. Uwaga ta dotyczyła również orzecznictwa karno-administracyjnego, którego podstawową wadą był „ścisły związek

1 Dz. U. Nr 75, poz. 444.

W. F. Dąbrowski, Zagadnienia ogólne orzecznictwa karno-administracyjnego, Poznań 1970, s. $22-23$.

3 M. Zimmermann, Zagadnienia kodyfikacji prawa i postępowania karno-administracyjnego, Notatka z 1962 r., Archiwum Akt Nowych, Zespół akt Ministerstwo Sprawiedliwości, sygn., teczki 2010, s. 100 (AAN MS 2010, s. 100).

${ }^{4}$ M. Zimmermann, Orzecznictwo karno-administracyjne, „Zagadnienia Karno-Administracyjne” (dalej: ZK-A) 1965, nr 4, s. 6. 
z ustrojem gospodarki liberalnej, który wymagał sprowadzenia administracji do roli stróża porządku publicznego"s. Przedwojenny model orzecznictwa karno-administracyjnego nie stanowił zatem skutecznego narzędzia realizacji zadań postawionych przed administracją w państwie budującym socjalizm.

Nawiązując do teorii i ustawodawstwa radzieckiego, lansowano teorię o społeczno-wychowawczej roli administracji. Aparat administracji miał „wychowywać społeczeństwo w duchu przestrzegania ustaw, zasad współżycia społecznego, wzajemnej pomocy"' . Oddziaływanie wychowawcze polegało przede wszystkim na uświadamianiu i przekonywaniu obywateli, wobec których przymus państwowy pełnił rolę drugoplanową ${ }^{7}$. Podkreślając znaczenie środków wychowawczych, czerpano ze słów Stalina: „represje w dziedzinie budownictwa socjalistycznego są niezbędnym elementem ofensywy, lecz elementem pomocniczym, a nie głównym". Zgodnie z tą teorią, przysługujące organom administracji prawo karania miało służyć realizacji zadań wychowawczych państwa socjalistycznego, a wykroczenie stanowiło akt nieposłuszeństwa wobec tych zdań ${ }^{8}$.

W Polsce Ludowej kary administracyjne miały mieć charakter represyjny wtedy, gdy służyły potrzebom walki klasowej prowadzonej „wobec jednostek wrogich, które działają z polecenia lub pod wpływem wrogich sił"9. W odniesieniu do wykroczeń popełnianych przez pozostałych obywateli kara administracyjna przestawała być wyłącznie elementem przymusu, gdyż na pierwszy plan wysuwano jej znaczenie wychowawcze ${ }^{10}$. Podstawowym celem polityki stosowania kar administracyjnych stała się zatem prewencja specjalna $\mathrm{w}$ postaci wychowawczego oddziaływania na sprawców wykroczeń ${ }^{11}$. Przez wpływanie na psychikę człowieka w kierunku wyzbycia się „nawyków, tkwiących w jego świadomości ukształtowanej pod wpływem ideologii burżuazyjnej", kary administracyjne miały kształtować pożądane przez władze postawy obywatelskie ${ }^{12}$. Zadanie kar administracyjnych polegało na „wdrażaniu mas pracujących do socjalistycznych zasad zbiorowego współżycia”, czyli przestrzegania prawa i wykonywania obowiązków wobec państwa.

Podkreślaniu znaczenia funkcji wychowawczej kar administracyjnych towarzyszyło pomijanie represyjnego aspektu kary grzywny, najczęściej stosowanego

${ }^{5}$ W. F. Dąbrowski, Zagadnienia ogólne orzecznictwa karno-administracyjnego, s. 45.

${ }^{6}$ M. Zimmermann, Orzecznictwo..., s. 7.

Z. Salwa, Wychowawcza rola prawa Polski Ludowej, Warszawa 1954, s. 49.

8 A. Marek, Problemy reformy polskiego prawa wykroczeń, [w:] Problemy odpowiedzialności karnej. Księga pamiątkowa ku czci Profesora Kazimierza Buchały, Kraków 1994, s. 195.

${ }_{9}$ Opór wroga klasowego miał wyrażać się „w stałym, uporczywym uchylaniu się od wykonywania obowiązków wobec państwa, w naruszaniu zasad zbiorowego współżycia, w zakłócaniu porządku i spokoju publicznego". R. Rajkowski, Prawo karno-administracyjne Polski Ludowej, Warszawa 1955, s. $81-82$.

${ }^{10}$ O pracy kolegiów orzekających w postępowaniu karno-administracyjnym, Warszawa 1952, s. 6-7.

${ }^{11}$ A. Gubiński, Kary zasadnicze w projekcie prawa o wykroczeniach, ZK-A 1969, nr 2, s. 32.

${ }^{12}$ R. Rajkowski, Prawo karno-administracyjne..., s. 82. 
środka karnego przez administrację państwa socjalistycznego. Fiskalny charakter grzywny, wyrażający się w dolegliwości materialnej zadanej ukaranemu, traktowano jako poboczny aspekt wychowawczego oddziaływania tej kary. Istotnej ze względów propagandowych funkcji wychowawczej nie mogło realizować oparte na odmiennych założeniach przedwojenne orzecznictwo karno-administracyjne, które w związku z tym "nie odpowiadało warunkom i potrzebom państwa ludowego". Cechował je "wybitny charakter represyjny, a nie wychowawczy”, przez co nie miało ono „realnych możliwości oddziaływania na kształtowanie się polityki administracji w kierunku społeczno-wychowawczym"13.

Socjalistyczną teorię kary administracyjnej wykorzystano jako argument przemawiający za zasadnością przeprowadzenia w grudniu $1951 \mathrm{r}$. gruntownej reformy orzecznictwa w sprawach o wykroczenia. Uzasadniając na forum Sejmu Ustawodawczego projektowane zmiany, poseł sprawozdawca podkreślał znaczenie funkcji wychowawczej orzecznictwa karno-administracyjnego, „nieznanej i niedostępnej mu w poprzedniej epoce" ${ }^{14}$. Bazowano oczywiście na jedynie słusznych wówczas „doświadczeniach Związku Radzieckiego"15. Według poglądów doktryny radzieckiej podstawowe zadanie organów administracji państwowej polegało na odpowiednim oddziaływaniu na obywateli w kierunku określonego ich postępowania. Oddziaływanie to przybierało formy przekonywania i zachęcania, dopiero $\mathrm{w}$ razie nieskuteczności tych środków mogło przybrać formę przymusu państwowego ${ }^{16}$. Orzecznictwo karno-administracyjne miało w związku z tym charakter wychowawczy, w poszczególnych republikach ZSRR zaś było traktowane jako stosowanie środków społeczno-wychowawczych ${ }^{17}$. System kar administracyjnych łączył w sobie dolegliwość natury materialnej z potępieniem moralnym i obowiązkiem pracy. Charakter kar majątkowych miały grzywna ${ }^{18} \mathrm{i}$ konfiskata mienia ${ }^{19}$, elementy wychowawcze cechowały upomnienie, które stosowano $\mathrm{w}$ razie popełnienia drobnego wykroczenia przez

${ }^{13}$ M. Jaroszyński, M. Zimmermann, W. Brzeziński, Polskie prawo administracyjne, Warszawa 1956, S. 419 .

${ }^{14}$ Wychowawcza funkcja orzecznictwa karno-administracyjnego miała być w szczególności realizowana wobec tych obywateli, którym „niewyplenione dotąd przeżytki starej świadomości burżuazyjnej niejednokrotnie utrudniają zrozumienie własnych najgłębszych interesów, w całości zbieżnych z dążeniami i walka naszego państwa o pełne zwycięstwo socjalistycznych stosunków społecznych”. Stenogram sejmowy z 99 posiedzenia Sejmu Ustawodawczego z dnia 15 grudnia 1951 r., łam 32.

${ }^{15}$ R. Rajkowski, Prawo karno-administracyjne..., s. 19.

${ }^{16}$ W. F. Dąbrowski, Zagadnienia ogólne orzecznictwa karno-administracyjnego..., s. 30.

${ }^{17}$ M. Jaroszyński, M. Zimmermann, W. Brzeziński, Polskie prawo..., op. cit., s. 413.

${ }^{18}$ Kara grzywny miała być najczęściej stosowana w stosunku do sprawców dopuszczających się poważniejszych wykroczeń, a także w przypadku nieskuteczności wcześniejszego upomnienia. Uzasadnienie projektu dekretu o orzecznictwie karno-administracyjnym z 1951 r., AAN MS 1969 s. 168.

${ }^{19}$ Konfiskata była stosowana w wypadkach stwierdzenia nabycia przez sprawcę wykroczenia przedmiotów uzyskanych nielegalnie, np. „z obejściem przepisów celnych, upolowanej bezprawnie zwierzyny, przedmiotów nabytych w celach spekulacyjnych". Uzasadnienie projektu dekretu o orzecznictwie..., s. 168. 
sprawcę niedostatecznie uświadomionego ${ }^{20}$. Połączenie dolegliwości materialnej $\mathrm{z}$ wychowaniem przez pracę miało miejsce w przypadku przymusowej pracy poprawczej $^{21}$. W praktyce stosowano ją wobec osób „niepoprawnych i złośliwie powtarzających wykroczenia"22. Ojczyzną kary pracy poprawczej był ZSRR. Praca poprawcza została tam wprowadzona przez kodeks karny z 1922 r. w wymiarze od 1 dnia do $1 \mathrm{roku}^{23}$. W $1931 \mathrm{r}$. została ona recypowana do orzecznictwa karno-administracyjnego, różniąc się od swojego pierwowzoru jedynie wymiarem kary, który w przypadku wykroczeń nie przekraczał 1 miesiąca ${ }^{24}$.

Kara administracyjna przymusowej pracy poprawczej miała zarówno charakter kary samoistnej, jak też kary zastępczej wymierzanej w przypadku nieuiszczenia grzywny. Karę tę odbywało się bez pozbawienia wolności, przy czym skazany wykonywał pracę $\mathrm{w}$ miejscu swojego dotychczasowego zatrudnienia. Osoby nie pozostające w stosunku pracy były kierowane w celu odbycia kary do zakładów znajdujących się w miejscu ich zamieszkania. Dolegliwość materialna kary polegała na potrąceniu odpowiedniej części wynagrodzenia wskazanej w orzeczeniu o ukaraniu, nie większej jednak niż $25 \%$. Odbywanie kary pracy poprawczej pociągało za sobą utratę przywilejów pracowniczych, takich jak prawo do urlopu, czy też wypłata wszelkich dodatków do wynagrodzenia. Czasu odbywania kary nie wliczano do ogólnego stażu pracy, do okresu niezbędnego do zdobycia określonych kwalifikacji, jak również do okresu dającego prawo do emerytury ${ }^{25}$.

Wzorce radzieckie stanowiły podstawę wprowadzenia w Polsce Ludowej nowej koncepcji karania za wykroczenia, której wyrazem była ustawa z 15 grudnia 1951 r. o orzecznictwie karno-administracyjnym ${ }^{26}$ (zwana dalej ustawą z 15 grudnia 1951 r.). Orzecznictwo to miało stanowić jedno z ogniw całego systemu środków wychowawczych ${ }^{27}$. Jego podstawowym zadaniem było „takie wychowanie społeczeństwa, aby ustalone normy współżycia społecznego były świadomie i dobrowolnie przestrzegane" ${ }^{28}$. Filarami tej koncepcji były zasada kolegialnego orzekania w sprawach o wykroczenia oraz połączenie stosowania środków karnych z metodą przekonywania i społecznego oddziaływania. Kara

${ }^{20}$ Ibidem.

${ }^{21}$ M. Jaroszyński, M. Zimmermann, W. Brzeziński, Polskie prawo..., s. 413.

${ }^{22}$ Uzasadnienie projektu dekretu o orzecznictwie..., s. 168.

${ }^{23}$ Tryb jej odbywania regulował specjalnie w tym celu wydany kodeks pracy poprawczej, w którym podkreślano znaczenie wychowawcze tej kary. Notatka Ministerstwa Sprawiedliwości z 1961 r. w sprawie kary pracy poprawczej, AAN MS 154, s. 3.

${ }^{24}$ R. Rajkowski, Prawo karno-administracyjne..., s. 21.

${ }^{25}$ Uzasadnienie projektu dekretu o orzecznictwie..., s. 168.

${ }^{26}$ Dz. U. Nr 66, poz. 454.

${ }^{27}$ M. Zimmermann, Orzecznictwo..., op. cit., s. 8.

${ }^{28}$ O realizację orzeczeń kolegiów karno-administracyjnych, „Poradnik dla Kolegiów Orzekających” 1956, nr 2, s. 3. 
miała stanowić środek, za pomocą którego kolegia „spełniają swoje zadania wychowawcze"29.

Praktyczna realizacja powyższych założeń skutkowała powierzeniem orzecznictwa karno-administracyjnego kolegiom przy prezydiach rad narodowych, począwszy od szczebla gromadzkiego. Postępowanie przed kolegiami było dwuinstancyjne. Odwołanie do kolegiów wyższego stopnia wprowadzono w miejsce dotychczasowego żądania skierowania sprawy na drogę sądową, pogarszając drastycznie sytuację ukaranego. Członkowie kolegiów byli wybierani przez rady narodowe spośród kandydatów przedstawionych przez organizacje społeczne, czyli w praktyce przez partię rządzącą. Znajomość środowiska obwinionego przez wywodzących się z tego samego terenu członków składów orzekających miała umożliwić bardziej wszechstronne zbadanie sprawy i zastosowanie najbardziej adekwatnych pod względem wychowawczym środków ${ }^{30}$. Wymierzanie kar przez tak dobranych członków kolegiów miało powodować, iż orzeczenia o ukaraniu w znacznie większym niż dotychczas stopniu „nabierały charakteru ujemnej oceny czynu sprawcy i jego potępienia przez przedstawicieli społeczeństwa"31. Również postępowanie karno-administracyjne próbowano kształtować $\mathrm{z}$ uwzględnieniem wychowawczej funkcji orzecznictwa, przewidując m.in. zapraszanie na rozprawę przedstawicieli organizacji społecznej, do której należał obwiniony ${ }^{32}$.

Wychowawczą koncepcję orzecznictwa karno-administracyjnego oddawał system kar, którym nadano „charakter odpowiadający roli represji w państwie budującym socjalizm" ${ }^{33}$. Z dotychczasowych kar utrzymano grzywnę, jednak jej faktyczna dolegliwość była znacznie niższa niż w okresie międzywojennym ${ }^{34}$. Węzłowym ogniwem reformy był zakaz orzekania aresztu, zarówno jako kary zasadniczej, jak tez kary zastępczej na wypadek nieuiszczenia grzywny. W miejsce aresztu wprowadzono karę pracy poprawczej ${ }^{35}$, która również była orzekana

${ }^{29}$ Ibidem, s. 4.

${ }^{30}$ M. Jaroszyński, M. Zimmermann, W. Brzeziński, Polskie prawo..., s. 420.

${ }^{31}$ H. Chmielewski, Dziesięć lat, ZK-A 1961, nr 6, s. 6.

${ }^{32}$ M. Jaroszyński, M. Zimmermann, W. Brzeziński, Polskie prawo..., s. 420.

${ }^{33}$ R. Rajkowski, Prawo karno-administracyjne, s. 85.

${ }^{34}$ Wynikało to $\mathrm{z}$ faktu utrzymania górnej granicy tej kary na poziomie przewidzianym przez przedwojenne ustawodawstwo, podczas gdy realna wartość 3000 złotych w latach pięćdziesiątych była zdecydowanie niższa. O pracy kolegiów orzekających..., s. 37.

${ }^{35}$ Podobny charakter do kary pracy poprawczej miała kara sądowa, polegająca na obowiązku pozostawania przez okres do 3 miesięcy w pracy dotychczas wykonywanej, z jednoczesnym potrąceniem od $10 \%$ do $25 \%$ wynagrodzenia miesięcznego. Była ona wymierzana na podstawie przepisów ustawy z 19 kwietnia 1950 r. o zabezpieczeniu socjalistycznej dyscypliny pracy (Dz. U. Nr 20, poz. 168). Naruszenie dyscypliny pracy polegało na opuszczeniu mimo wymierzonych kar porządkowych bez usprawiedliwienia w ciągu roku czterech lub więcej dni pracy albo opuszczenie jednorazowo bez usprawiedliwienia czterech lub więcej dni pracy. Czyn ten zagrożony był karą sądową. W przypadku uchylania się od odbycia kary sądowej przewidziana była kara 6 miesięcy aresztu. Ustawa ta została uchylona ustawą z dnia 10 września 1956 r. w sprawie uchylenia przepisów o zabezpieczeniu socjalistycznej dyscypli- 
jako kara zastępcza w razie stwierdzenia nieściągalności orzeczonych grzywien. Dążąc do ściślejszego powiązania wymiaru kary z czynem, jego okolicznościami i osobowością sprawcy, kolegia zostały upoważnione do stosowania upomnienia zamiast kary, jeżeli szkodliwość społeczna czynu była niewielka ${ }^{36}$. Upomnienie stanowiło środek nadzwyczajnego wymiaru kary i miało charakter dolegliwości wyłącznie moralnej.

W rzeczywistości przewidziany w ustawie z 15 grudnia 1951 r. system kar administracyjnych opierał się represji ekonomicznej, której elementy występowały w dwóch podstawowych środkach karnych: grzywnie i pracy poprawczej. O ile kara grzywny w założeniu miała na celu wyrządzenie ukaranemu dolegliwości materialnej, to $z$ karą pracy poprawczej wiązano duże nadzieje wychowawcze ze względu na zawarty w niej obowiązek pracy ${ }^{37}$.

\section{Istota kary pracy poprawczej}

Wprowadzenie kary pracy poprawczej, łączącej presję ekonomiczną z obowiązkiem pracy, miało wzbogacić katalog środków karnych i uelastycznić sposób reagowania na wykroczenia. Wynikało to $\mathrm{z}$ faktu odejścia od istniejącej poprzednio sztywnej regulacji, nakazującej w razie ustalenia znamion wykroczenia zastosowanie aresztu lub grzywny ${ }^{38}$.

W założeniu autorów reformy orzecznictwa karno-administracyjnego kara pracy poprawczej miała na celu zmniejszenie zakresu stosowania kary aresztu, który utrzymano jedynie w odniesieniu do najpoważniejszych wykroczeń przekazywanych przez kolegia na drogę postępowania sądowego. Wyłączenie stosowania kary aresztu przez kolegia nie wynikało tylko z przesłanek natury ideologicznej w postaci przejmowania wzorców radzieckich, gdyż u podstaw tego rozwiązania legły także względy natury praktycznej. Masowe stosowanie represji wobec przeciwników politycznych nowej władzy oraz traktowanie prawa karnego jako instrumentu służącego zapewnieniu prawidłowego funkcjonowania gospodarki planowej skutkowało przepełnieniem więzień i aresztów, które zajmowali skazani za przestępstwa w postępowaniu sądowym. W przypadku sprawców wykroczeń ukaranych aresztem występowały poważne trudności

ny pracy (Dz. U. Nr 41, poz. 187). M. Melezini, Punitywność wymiaru sprawiedliwości karnej w Polsce w XX wieku, Białystok 2003, s. 75 .

${ }^{36}$ Jeżeli zaś szkodliwość społeczna czynu była na tyle znaczna, iż należałoby zastosować przewidzianą przez obowiązujące przepisy karę aresztu, wówczas miało miejsce przekazanie sprawy na drogę postępowania sądowego. Przed rozpoczęciem rozprawy kompetencja ta przysługiwała przewodniczącemu kolegium, a po wyznaczeniu rozprawy składowi orzekającemu. M. Zimmermann, Orzecznictwo..., op. cit., s. 9 .

${ }^{37}$ A. Gubiński, Kary zasadnicze w projekcie prawa..., s. 32.

${ }^{38}$ A. Gubiński, Ewolucja stosowanych przez kolegia środków karnych i zasad wymiaru kary, „Zagadnienia Wykroczeń" 1977, nr 6, s. 28. 
Z wykonaniem kary, które pogłębiał „brak aresztów w wielu miastach i gminach”. Zwrócono na to uwagę podczas debaty sejmowej nad ustawą z 15 grudnia $1951 \mathrm{r}$. przyznając, że „pozbawienie wolności przy jednoczesnym braku aresztu w wielu miastach i gminach zapewniało bezkarność wielu przestępczym elementom"39. Trudności te doprowadziły do powstania poważnych zaległości w wykonaniu kary aresztu ${ }^{40}$. Z kolei nieskuteczność zastępczej kary aresztu prowadziła do tego, że,„zaległości w nieściągniętych a zasądzonych grzywnach wzrastają z roku na rok" ${ }^{\prime 1}$.

Nadziei na poprawę sytuacji w zakresie wykonywania orzeczeń karno-administracyjnych upatrywano w karze pracy poprawczej. Podczas debaty sejmowej nad projektem ustawy z 15 grudnia 1951 r. wyrażono pogląd, iż „wprowadzenie w miejsce kary aresztu pracy poprawczej ma głębokie znaczenie społeczne. Zapewnia to bowiem skuteczność wymierzonej kary" ${ }^{42}$. Kara pracy poprawczej mogła być orzekana w wymiarze od 1 dnia do 3 miesięcy $^{43}$, czyli w wymiarze analogicznym jak dotychczas obowiązująca kara aresztu ${ }^{44}$. Ukarany nie był pozbawiony wolności, lecz zobowiązany do wykonywania pracy w swoim zakładzie przy jednoczesnym potrąceniu 20\% wynagrodzenia na rzecz Skarbu Państwa. Osoby zatrudnione w sektorze państwowym lub organach administracji odbywały karę pracy poprawczej w miejscu swojego dotychczasowego zatrudnienia. Wprawdzie nie wynikało to wprost $\mathrm{z}$ obowiązujących uregulowań, lecz z istoty kary poprawczej wywodzono zawieszenie prawa rozwiązania umowy o pracę z inicjatywy osoby ukaranej. Zwolnienie ukaranego pracownika przez zakład pracy uważano za możliwe jedynie w sytuacji, gdy było to konieczne z uwagi na konkretne warunki panujące w danym zakładzie, np. brak możliwości dalszego zatrudnienia pracownika ${ }^{45}$.

Pracownicy zakładów prywatnych odbywali karę w miejscu swojego zatrudnienia, jeżeli ich zakład posiadał określone znaczenie gospodarcze. Rozstrzygały o tym prezydia rad narodowych, które nadzorowały i kontrolowały wykonanie kary pracy poprawczej. Jeżeli zdaniem prezydium rady narodowej zakład pry-

${ }^{39}$ Sprawozdanie stenograficzne z 99 posiedzenia..., łam 36.

${ }^{40}$ Zaległości te występowały w stosunku do 42500 osób według stanu na koniec $1951 \mathrm{r}$. W samym 1950 r. na 57815 orzeczeń o ukaraniu aresztem nie zdołano wykonać tej kary wobec 15577 osób. Uzasadnienie projektu dekretu o orzecznictwie..., s. 166-167.

${ }^{41}$ Zaległości w egzekwowaniu orzeczonych kar grzywny wynosiły w połowie 1951 r. „około 19 milionów złotych, a w stosunku do nałożonych tylko w 1950 roku grzywien stanowią 30\% (7707 tys. na 26737 tys.)". Uzasadnienie projektu dekretu o orzecznictwie..., s. 166-167.

${ }^{42}$ Sprawozdanie stenograficzne $z 99$ posiedzenia.., łam 36.

${ }^{43}$ Karę pracy poprawczej wymierzono $\mathrm{w}$ dniach, tygodniach i miesiącach, przyjmując 6 dni pracy za równoważne jednemu tygodniowi, zaś 25 dni jako odpowiadające miesiącowi. Z. Rybicki, Gospodarcze aspekty orzecznictwa karno-administracyjnego, „Przegląd Ustawodawstwa Gospodarczego” 1952 , nr 9, s. 321.

${ }^{44}$ Ibidem, s. 320.

${ }^{45}$ R. Rajkowski, Prawo karno-administracyjne, s. 236. 
watny nie posiadał znaczenia gospodarczego, to ukaranych kierowano do jednostek gospodarki uspołecznionej celem odbycia tam kary. Podobnie postępowano w przypadku ukaranych nieposiadających stałego miejsca zatrudnienia oraz osób nigdzie niepracujących ${ }^{46}$. W odniesieniu do niepracujących kara pracy poprawczej posiadała szczególne walory wychowawcze, gdyż obowiązek podjęcia wskazanej pracy miał wdrażać takie osoby do pracy i uczyć szacunku dla pracujących ${ }^{47}$. Zakład pracy powinien wyznaczyć ukaranemu miejsce i rodzaj pracy odpowiadającej jego kwalifikacjom oraz określić wynagrodzenie, z którego potrącano 20\% na rzecz Skarbu Państwa. Dopuszczalne było zatrudnianie tej grupy ukaranych bez wynagrodzenia; wówczas przyjmowano jeden dzień pracy bez wynagrodzenia za równoważny trzem do pięciu dni pracy wynagradzanejej ${ }^{48}$.

Realizacji funkcji wychowawczej tej kary służyło upoważnienie kolegiów do nakazania podania treści orzeczenia do wiadomości publicznej na tablicy ogłoszeń gromadzkich bądź w zakładzie pracy ukaranego ${ }^{49}$. To właśnie zawstydzenie i napiętnowanie publiczne sprawcy wykroczenia miało stanowić istotę wychowawczej funkcji kary poprawczej. Na dalszy plan spychano ekonomiczną dolegliwość tej kary, polegającą na potrącaniu $20 \%$ wynagrodzenia ukaranego, wskazując, że „nie w tym tkwi głęboki sens i wychowawczy charakter tego środka represji". Konsekwencją odbywania kary w zakładzie pracy miało być poinformowanie współpracowników i znajomych ukaranego o fakcie popełnienia wykroczenia. Takie czynniki, jak „potępienie opinii społecznej, potępienie towarzyszy pracy, zawstydzenie" uważano za nieodłącznie związane z karą pracy poprawczej. Przypisywano im istotne znaczenie „we wdrażaniu ukaranego do przestrzegania zasad socjalistycznego współżycia”. Oddziaływanie wychowawcze kary pracy poprawczej obejmowało także współpracowników ukaranego, gdyż kara ta „budzi w nich czujność klasową i przestrzega przed naruszaniem ludowego porządku prawnego" ${ }^{50}$.

Rozporządzenie wykonawcze do ustawy z 15 grudnia $1951 \mathrm{r} \cdot{ }^{51}$ nakładało na zakłady pracy obowiązek czuwania nad wykonaniem orzeczonej kary, zwłaszcza informowania prezydium właściwej rady narodowej o niezgłoszeniu się ukaranego do pracy lub opuszczeniu pracy bez należytego usprawiedliwienia. Uchylanie się od odbycia kary stanowiło przestępstwo zagrożone karą aresztu do 6 miesięcy. Wprowadzenie sankcji sądowych służyło zabezpieczeniu realizacji kary pracy poprawczej, która była wykonywana bez pozbawienia wolności

\footnotetext{
${ }^{46}$ Z. Rybicki, Gospodarcze aspekty orzecznictwa..., s. 321 .

${ }^{47}$ W. F. Dąbrowski, Zagadnienia ogólne orzecznictwa karno-administracyjnego..., s. 56.

${ }^{48} \mathrm{~J}$. Chełmoński, J. Malinowski, Otrzymałem wezwanie do kolegium karno-administracyjnego, Warszawa 1957, s. 58-59.

${ }^{49}$ Uzasadnienie projektu dekretu o orzecznictwie..., s. 170.

${ }^{50}$ O pracy kolegiów orzekających..., s. 37.

${ }^{51}$ Rozporządzenie Rady Ministrów z dnia 15 grudnia 1951 r. w sprawie zasad i trybu odbywania kary pracy poprawczej (Dz. U. Nr 66, poz. 457).
} 
i bezpośredniego stosowania przymusu. Groźba zastosowania represji karnej w trybie postępowania sądowego miała „powstrzymywać skazanych na karę pracy poprawczej od lekceważenia orzeczeń kolegiów"52.

Kara pracy poprawczej była stosowana również jako kara zastępcza w przypadku nieuiszczenia orzeczonej grzywny ${ }^{53}$. Kolegia orzekały zastępczą karę pracy poprawczej dopiero po stwierdzeniu nieściągalności grzywny, gdyż w ustawie z 15 grudnia $1951 \mathrm{r}$. brak było podstaw do określenia wymiaru tej kary jednocześnie $\mathrm{z}$ wydaniem orzeczenia skazującego ${ }^{54}$. Inną wadą wprowadzonych rozwiązań był brak ustawowej regulacji, zakazującej stosowania kary zastępczej, jeżeli warunki osobiste ukaranego nie pozwalały na odbycie tej kary, jak też nakazującej zmniejszenie jej rozmiaru w wypadku częściowego zapłacenia grzywny ${ }^{55}$.

\section{Praktyka stosowania kary pracy poprawczej w okresie stalinowskim}

Praktyka orzekania kary pracy poprawczej daleko odbiegała od pokładanych $\mathrm{w}$ tej karze nadziei, gdyż w dalszym ciągu dominującym środkiem represyjnym pozostała grzywna. Kara pracy poprawczej w latach 1952-1954 stosowana była dosyć ostrożnie. Dopiero w latach kolejnych nastąpił kilkuprocentowy wzrost udziału tego środka w strukturze kar, co należy wiązać z pewnym zaostrzeniem represyjności polityki karnej kolegiów ${ }^{56}$. Proces ten był konsekwencją przejęcia w 1954 r. nadzoru nad orzecznictwem karno-administracyjnym przez Ministerstwo Spraw Wewnętrznych ${ }^{57}$, które w przypadku kary pracy poprawczej „bardzo mocno w swoich instrukcjach i poprzez terenowy aparat k-a nakłaniało kolegia do możliwie najszerszego jej stosowania" ${ }^{\text {. }}$. Wysiłki MSW nie przyniosły oczekiwanych rezultatów, gdyż procentowy wskaźnik udziału kary pracy poprawczej w całokształcie orzekanych kar nigdy nie przekroczył 10\%. Najlepszy pod tym względem był rok 1957, kiedy to kara pracy poprawczej stanowiła 9,6\% ogólnej liczby wymierzonych kar. Najgorsze wyniki natomiast zanotowano w latach 1952-1954. Wtedy odsetek orzeczonych kar pracy poprawczej wahał się w gra-

${ }^{52}$ R. Rajkowski, Prawo karno-administracyjne, s. 237.

${ }^{53}$ Zastępczą karę pracy poprawczej orzekano, przyjmując jeden dzień tej kary jako równowartość grzywny w wymiarze od 10 do 40 złotych. Wymiar kary zastępczej nie mógł przekroczyć jego ustawowego maksimum, czyli 3 miesięcy. J. Jakubowska-Hara, Grzywna w prawie wykroczeń, Warszawa 2004, s. 41.

${ }^{54}$ R. Rajkowski, Prawo karno-administracyjne, s. 91.

${ }^{55}$ R. Rajkowski, Projekt kodeksu karnego a prawo karno-administracyjne i jego problemy kodyfikacyjne, „Państwo i Prawo” (dalej: PiP) 1956, nr 8-9, s. 332.

${ }^{56}$ J. Jakubowska-Hara, Grzywna..., op. cit., s. 44.

${ }^{57}$ Od 1954 r. minister spraw wewnętrznych sprawował zwierzchni nadzór nad działalnością kolegiów; nadzór bezpośredni wykonywały prezydia odpowiednich rad narodowych. M. Zimmermann, Orzecznictwo..., s. 9.

${ }^{58}$ Notatka w sprawie kary pracy poprawczej. Sporzadzona 10 czerwca 1960 r. przez Dyrektora Departamentu Społeczno-Administracyjnego Ministerstwa Spraw Wewnętrznych, AAN MS 154, s. 6. 
nicach od 4,3\% do 4,8\% ${ }^{59}$. Z wprowadzonych przez ustawę z 15 grudnia 1951 roku nowych środków karnych lepiej w praktyce wypadło upomnienie, którego wskaźnik stosowania oscylował w granicach kilkunastu procent ${ }^{60}$.

Strukturę orzeczonych przez kolegia kar pracy poprawczej na tle ogólnej liczby środków karnych obrazuje poniższa tabela.

\begin{tabular}{|c|c|c|c|}
\hline \multirow{2}{*}{ Rok } & Kolegia & orzekły kar & \multirow{2}{*}{$\begin{array}{c}\text { ogólny procent } \\
\text { wykonania kar }\end{array}$} \\
\cline { 2 - 3 } & ogółem & $\begin{array}{c}\text { w tym pracy } \\
\text { poprawczej }\end{array}$ & 40 \\
\hline 1952 & 895149 & 38969 & 31 \\
\hline 1953 & 1382819 & 66952 & 31 \\
\hline 1954 & 1290180 & 87570 & 62 \\
\hline 1955 & 982595 & 90543 & 49 \\
\hline 1956 & 631557 & 73257 & 58 \\
\hline 1957 & 628247 & 55553 & 61 \\
\hline 1958 & 819364 & 24042 & 6 \\
\hline
\end{tabular}

Źródło: Notatka MSW w sprawie kary pracy poprawczej z 10 IV 1960 r., AAN MS 154, s. 6.

Zdaniem MSW przytoczone dane statystyczne świadczyły o braku zaufania składów orzekających kolegiów do kary pracy poprawczej i niewiele pomogły tutaj podejmowane przez ministerstwo wysiłki w kierunku zwiększenia zakresu stosowania tej kary. Przyczyną takiego stanu rzeczy były trudności z wykonywaniem orzeczonych kar pracy poprawczej, przez co kolegia spotkały się z zarzutem braku wychowawczego oddziaływania na społeczeństwo. Zarzuty te nie były bezpodstawne, gdyż wykonywanie orzeczonych kar pracy poprawczej miało miejsce w zaledwie 40-65\%, co w opinii MSW „przy milionowym wpływie spraw dawało setki tysięcy niewykonanych kar w skali krajowej". Niska skuteczność kary pracy poprawczej dalece ograniczała znaczenie wychowawcze tej kary, co demoralizowało społeczeństwo, utwierdzając je w przekonaniu o faktycznej bezkarności wykroczeń ${ }^{11}$. Uwagi te w równym stopniu dotyczą kary pracy poprawczej orzekanej w przypadku nieściągalności grzywny, co podważało skuteczność represji ekonomicznej tkwiącej w karze grzywny. Problemy z wykonaniem kary pracy poprawczej rzutowały na skuteczność całego systemu orzecznictwa karno-administracyjnego, prowadząc do sytuacji, w której wykonalność orzeczonych kar w wielu rejonach kraju nie przekraczała $50 \%{ }^{62}$. Ponad połowa orzeczonych kar nie była realizowana w przewidzianym przez ustawę

\footnotetext{
${ }^{59}$ Ibidem.

${ }^{60}$ J. Jakubowska-Hara, Grzywna...., op. cit., s. 44.

${ }^{61}$ Notatka $w$ sprawie kary pracy..., s. 10.

${ }^{62}$ Uzasadnienie do projektu pierwszej redakcji prawa karno-administracyjnego, Warszawa 1957,
} s. 12 . 
z 15 grudnia 1951 r. terminie 6 miesięcy od uprawomocnienia się orzeczenia, co prowadziło do przedawnienia wykonania.

Korzyści z takiego stanu rzeczy odnosiły zwłaszcza jednostki określane w Polsce Ludowej jako „elementy chuligańskie i pasożytnicze”, czyli osoby z reguły nigdzie nie pracujące ${ }^{63}$. Osoby takie nie posiadały oficjalnych dochodów, co bardzo utrudniało wykonywanie orzeczonych kar grzywny, zamienianych następnie na zastępczą karę pracy poprawczej. W celu realizacji orzeczonej kary pracy poprawczej prezydium rady narodowej powinno znaleźć zatrudnienie odpowiadające $\mathrm{w}$ miarę możliwości kwalifikacjom ukaranego, a te $\mathrm{z}$ reguły były niskie. Ta grupa ukaranych mogła być zatrudniona jedynie przy pracy fizycznej, w przypadku której szczególne kwalifikacje nie były potrzebne. W praktyce zakłady pracy bardzo niechętnie przyjmowały osoby skazane na karę pracy poprawczej, gdyż okres zatrudnienia takich osób był zbyt krótki z ekonomicznego punktu widzenia. Zakłady pracy były zmuszane do „tworzenia specjalnych etatów lub stanowisk dla ludzi niewykwalifikowanych w danych działach pracy, dla przypadkowych i zupełnie tymczasowych pracowników"64. Praca wykonywana przez skazanych $\mathrm{w}$ tak krótkim okresie zamiast korzyści ekonomicznych przynosiła straty, „skierowani bowiem w tym trybie do zakładu pracy pracowali źle lub w ogóle tylko markowali pracę". Nie można było stosować wobec takich osób ekonomicznych środków oddziaływania o charakterze motywacyjnym w postaci kar porządkowych, czy też obcięcia premii, gdyż nie były one zatrudnione na stałe. Kilku- lub co najwyżej kilkunastodniowych pracowników traktowano nieprzychylnie, ponieważ często wykazywali oni lekceważące podejście do wykonywania swoich obowiązków. Zwłaszcza załogi zakładów pracy cechowała niechęć wobec „bumelantów”, określanych tak z racji niechętnego stosunku do pracy i demoralizującego oddziaływania na pozostałych pracowników ${ }^{65}$.

Nic dziwnego, że kierownictwo zakładów pracy broniło się przed przyjmowaniem tymczasowych pracowników, zasłaniając się brakiem zapotrzebowania na pracowników niewykwalifikowanych. Nie bez racji wskazywano na brak funduszy na wynagrodzenia i ubezpieczenie osób skierowanych do pracy, gdyż wydatki tego rodzaju nie były wcześniej zaplanowane w budżetach zakładowych. $\mathrm{W}$ takiej sytuacji zatrudnianie osób niefigurujących na liście płac naruszałoby przepisy prawa pracy i narażało kierownictwo zakładu na sankcje ze strony inspekcji pracy. Negatywny stosunek dyrekcji zakładów pracy do przyjmowania osób skazanych potwierdza fakt skierowania do Ministerstwa Spraw Wewnętrznych pism przez poszczególne resorty gospodarcze „wręcz domagających się niekierowania do podległych im zakładów pracy ukaranych karą pracy poprawczej".

${ }^{63}$ W. F. Dąbrowski, Zagadnienia ogólne orzecznictwa karno-administracyjnego..., s. 57.

${ }^{64}$ Notatka Ministerstwa Sprawiedliwości..., s. 2.

${ }^{65}$ W. F. Dąbrowski, Zagadnienia ogólne orzecznictwa karno-administracyjnego..., s. 56. 
Wobec wyraźnej niechęci kierownictwa zakładów pracy, MSW podejmowało próby organizowania w ośrodkach miejskich „brygad pracy”, do których mieli trafiać skazani na pracę poprawczą. Problemem był jednak „brak uzbrojonych w dostateczne środki przymusu dozorców", ponadto ukarani z reguły nie zgłaszali się dobrowolnie do pracy. Zwracano się do MO z żądaniem przymusowego doprowadzenia ukaranych, jednakże działania milicji nie przynosiły oczekiwanych efektów zarówno „Z uwagi na szczupłość kadry milicyjnej, jak i potrzebę wielokrotnie powtarzanych prób odszukania ukaranego, który uchylał się od pracy"66.

W stosunku do ukaranych uchylających się od podjęcia wskazanej pracy ustawa z 15 grudnia 1951 r. przewidywała możliwość zastosowania środka przymusu w postaci aresztu. Jednak sądy bardzo niechętnie orzekały ten środek, zwracając $\mathrm{z}$ reguły akta kolegiom z zaleceniem stosowania grzywny. Przeciążenie sądów innymi zadaniami $\mathrm{w}$ połączeniu $\mathrm{z}$ 6-miesięcznym okresem przewidzianym na wykonanie orzeczeń kolegiów skutkowało częstym umorzeniem postępowania sądowego $\mathrm{w}$ sprawach związanych $\mathrm{z}$ uchylaniem się od pracy poprawczej z powodu przedawnienia.

Narastające trudności z wykonywaniem kary pracy poprawczej wobec osób niezatrudnionych w sektorze uspołecznionym, doprowadziły do tego, że w praktyce „kara ta obejmowała wyłącznie ludzi pracy najemnej” ${ }^{67}$, czyli zatrudnionych w przedsiębiorstwach państwowych i spółdzielniach produkcyjnych. Tutaj także pojawily się problemy, gdyż skazani uchylając się od wykonania kary często zmieniali miejsce pracy. Proceder ten pogłębiał niekorzystne pod względem ekonomicznym zjawisko płynności kadr, które wpływało niekorzystnie na realizację planów gospodarczych przez zakłady pracy. Najważniejsza przyczyna trudności tkwiła jednak w lekceważącym podejściu zakładów pracy do obowiązków związanych z wykonywaniem kary pracy poprawczej. Kierownictwo zakładów pracy zaniedbywało dokonywania potrąceń z wynagrodzeń osób ukaranych, nie podawało także do publicznej wiadomości załogi faktu ukarania pracownika. MSW zarzucało zakładom pracy niedostrzeganie propagandowego wykorzystania tej kary „w celu postawienia sprawcy wykroczenia pod pręgierzem opinii publicznej”. Jako przykład posłużyły Zakłady Włókien Sztucznych w Tomaszowie Mazowieckim, „gdzie do wykonawstwa kar pracy poprawczej przystępowano częstokroć w sposób niewłaściwy, ograniczając się do potrącania $20 \%$ z poborów obwinionego"68. Tym samym wypaczano ideę wychowawczego oddziaływania kary pracy poprawczej, która została w praktyce „pozbawiona swego najbardziej ostrego elementu wychowawczego, a mianowicie potępienia przez

\footnotetext{
${ }^{66}$ Notatka w sprawie kary pracy..., s. 7.

${ }^{67}$ Notatka Ministerstwa Sprawiedliwości..., s. 2.

${ }^{68}$ Nasze trudności (O wykonywaniu kar w woj. łódzkim), ZK-A 1956, nr 2-3, s. 15.
} 
współtowarzyszy pracy”69. O fakcie ukarania wiedział z reguły główny księgowy $\mathrm{z}$ racji obowiązku potrącania $\mathrm{z}$ wynagrodzenia skazanego $20 \%$ i przekazywania ich na rzecz Skarbu Państwa. Znacznie rzadziej wiedział o tym kierownik zakładu, bezpośredni przełożony, czy też koledzy pracujący przy sąsiednim stanowi$\mathrm{sku}^{70}$. W rezultacie kara pracy poprawczej posiadała wymiar finansowy, stanowiąc swego rodzaju grzywnę rozłożoną na dogodne dla ukaranego raty. Od kary grzywny praca poprawcza różniła się w praktyce nazwą oraz uprzywilejowaną sytuacją ukaranego. Skazany na zwykłą grzywnę był zobowiązany pod rygorem egzekucji do uiszczenia jej od razu w całości, podczas gdy ukarany karą pracy poprawczej taką samą sumę wpłacał w ratach miesięcznych ${ }^{71}$.

Sprawujące zwierzchni nadzór nad orzecznictwem karno-administracyjnym MSW próbowało walczyć $\mathrm{z}$ narastającymi trudnościom. Zdawało sobie jednak sprawę, iż dysponuje zbyt skromnymi środkami, żeby znacząco wpłynąć na poprawę stanu wykonywania kar pracy poprawczej. Zdaniem ministerstwa, „przeciwdziałanie takiemu stanowi rzeczy wymagało stworzenia szeroko rozbudowanego aparatu kontrolnego, na co nie było możliwości”72. Pomimo to ministerstwo podejmowało pewne działania, wykorzystując $\mathrm{w}$ tym celu podległe jednostki prezydiów rad narodowych. Zostały one zobowiązane do przeprowadzenia narad z kierownictwem zakładów pracy, które „opieszale dokonywały potrąceń z wynagrodzenia zatrudnionych u siebie pracowników”. Prezydia rad narodowych miały ponadto kontrolować terminowość dokonywania potrąceń $\mathrm{z}$ wynagrodzenia i występować $\mathrm{z}$ wnioskami do prokuratury o ukaranie winnych niedokonywania potrąceń. Celem wzmocnienia oddziaływania wychowawczego MSW nakazało prezydiom rad narodowych, by orzeczenia o ukaraniu pracą poprawczą były „, szerszej mierze podawane do publicznej wiadomości zakładów pracy zatrudniających ukaranych tą karą". MSW wystąpiło także z wnioskiem do Centralnej Rady Związków Zawodowych, żeby ta za pośrednictwem rad zakładowych zwróciła uwagę zakładom pracy na konieczność prawidłowego wykonywania kary pracy poprawczej.

Oceniając z perspektywy czasu podejmowane działania, samokrytycznie przyznano, że „wysiłki te dawały jednak stosunkowo niewielkie rezultaty”

Powyższa opinia została wyrażona w okresie gomułkowskim, kiedy w kontekście planowanej kodyfikacji praw wykroczeń dopuszczono rzetelną i krytyczną ocenę dotychczas funkcjonujących instytucji. Jednak w pierwszej połowie lat pięćdziesiątych, czasach propagandy sukcesu, trudno znaleźć krytyczne uwagi na temat praktycznej przydatności kary pracy poprawczej. Wręcz przeciwnie,

${ }^{69}$ W. F. Dąbrowski, Zagadnienia ogólne orzecznictwa karno-administracyjnego..., s. 56.

${ }^{70}$ Ibidem, s. 57.

${ }^{71}$ Notatka w sprawie kary pracy..., s. 8.

${ }^{72}$ Ibidem, s. 9.

${ }^{73}$ Ibidem. 
literatura prawnicza podkreślała nadzieje pokładane w wychowawczym oddziaływaniu tej kary, nadając jej rangę podstawowego środka karnego stosowanego przez kolegia. Obok problemów powstałych na tle praktycznego stosowania kary pracy poprawczej nie mogły natomiast przejść obojętnie władze partyjne i rządowe. W sposób pośredni problemy te wpływały na realizację założeń planu 6-letniego w zakresie socjalistycznej przebudowy gospodarki rolnej, gdzie ważną rolę odgrywały dostawy obowiązkowe płodów rolnych. Wzmocnieniu dyscypliny wykonania dostaw przez rolników indywidualnych służyło wprowadzenie kar grzywny orzekanych w trybie karno-administracyjnym wobec chłopów zalegających $z$ dostawami. Ponieważ ukarani często nie płacili orzeczonych grzywien, a ich przymusowa egzekucja była nieskuteczna, to kolegia stosowały zastępczą karę pracy poprawczej. Opisane wcześniej trudności z wykonywaniem tej kary wobec osób niezatrudnionych w sektorze uspołecznionym prowadziły do faktycznej bezkarności ukaranych rolników indywidualnych. Podważało to ideę dostaw obowiązkowych, które oprócz poprawy sytuacji aprowizacyjnej miast stanowiły instrument prowadzonej przez ówczesne władze walki klasowej przeciwko warstwie kułaków. Pojawiły się postulaty wzmocnienia represyjności orzecznictwa karno-administracyjnego, gdyż stosowane przez kolegia środki karne nie były w stanie należycie zabezpieczyć realizacji wyznaczonego administracji zadania przebudowy struktury gospodarki rolnej w duchu socjalistycznym $^{74}$. Powołując się na znaczenie dostaw obowiązkowych „dla budownictwa socjalistycznego i realizacji narodowych planów gospodarczych” podkreślano zwłaszcza konieczność wzmocnienia represji karno-administracyjnej „wobec tych, którzy nie wykonują obowiązków wobec państwa"75.

Wzmocnienie represji polegało na wprowadzeniu w marcu $1953 \mathrm{r}^{76}$ zastępczej kary aresztu w sprawach o niewykonanie dostaw obowiązkowych. Wymierzając karę grzywny za niewykonanie obowiązku dostawy zbóż, zwierząt rzeźnych, mleka lub ziemniaków, kolegia orzekały jednocześnie zastępczą karę aresztu na wypadek nieuiszczenia grzywny ${ }^{77}$. Wyłom od zasady nieorzekania aresztu w postępowaniu karno-administracyjnym uzasadniano w myśl typowej dla ustrojów totalitarnych zasady - „cel uświęca środki”. Wskutek odstępstwa od tej reguły „kolegia otrzymały broń, której stosowanie odgrywa poważną rolę w toczącej się walce klasowej z elementami kułackimi i ich poplecznikami"78. Oczywiście ani słowem nie wspomniano o niepowodzeniu eksperymentu polegającego na

${ }^{74}$ A. Gubiński, Ewolucja stosowanych przez kolegia środków karnych..., s. 28-29.

${ }^{75}$ R. Rajkowski, Prawo karno-administracyjne..., s. 81, przypis nr 6.

${ }^{76}$ Dekretem z dnia 4 marca 1953 r. o uzupełnieniu przepisów karnych w sprawach dostaw obowiązkowych (Dz. U. Nr 14, poz. 55)

${ }_{77}$ B. Adamiak, Ewolucja systemu kar w orzecznictwie w sprawie wykroczeń $w$ PRL, Acta Universitatis Wratislaviensis, Przegląd Prawa i Administracji VIII, Wrocław 1976, s. 107.

${ }^{78}$ R. Rajkowski, Prawo karno-administracyjne..., s. 94. 
zastąpieniu aresztu karą pracy poprawczej, lecz wynikało to w sposób oczywisty z faktu osłabienia funkcji wychowawczej orzecznictwa karno-administracyjnego kosztem wzmocnienia jego represyjności.

Po wprowadzeniu zastępczej kary aresztu praca poprawcza przestała odgrywać większą rolę w orzecznictwie karno-administracyjnym na terenach wiejskich, gdzie rozpatrywano głównie sprawy o wykroczenia związane z dostawami obowiązkowymi. Karę tę stosowały głównie kolegia przy prezydiach miejskich rad narodowych, chociaż czyniły to bez większego przekonania co do wartości wychowawczej pracy poprawczej. Dotyczyło to zwłaszcza najczęściej popełnianych $\mathrm{w}$ miastach wykroczeń chuligańskich ${ }^{79}$, w przypadku których kara pracy poprawczej była najczęściej stosowanym środkiem karnym ${ }^{80}$.

Świadomość trudności z wykonaniem orzeczeń powodowała, iż kolegia rzadko decydowały się na wymierzanie kary pracy poprawczej w maksymalnym wymiarze, $\mathrm{z}$ reguły oscylując wokół dolnej granicy ${ }^{81}$. Zbyt niski wymiar kar oraz przewlekłość w ich realizacji „tępiły ostrze wychowawcze” pracy poprawczej w odniesieniu do sprawców tzw. wykroczeń chuligańskich ${ }^{82}$. Wskutek niewłaściwego wykonywania kary pracy poprawczej funkcje prewencyjno-wychowawcze tej kary nie były w praktyce realizowane, gdyż nie odstraszała ona od popełniania dalszych wykroczeń ani nie wdrażała ukaranych do poszanowania porządku prawnego. Nieskuteczność kary pracy poprawczej prowadziła do powstania wśród sprawców wykroczeń o charakterze chuligańskim przekonania o bezkarności, co dotyczyło w szczególności tzw. „chuliganów-recydywistów”"3. Wskazuje na to sprawozdanie poświęcone trudnościom w wykonywaniu na terenie wo-

${ }^{79}$ Przykładowo w 1953 r. w Warszawie 90\% wykroczeń sprawców młodocianych uznano za popełnione w celu chuligańskim. Wykroczenia te polegały na zakłóceniu spokoju we wszystkich formach i zostały dokonane jedynie w celu okazania nieposzanowania dla zasad współżycia społecznego. Były to wykroczenia polegające na naruszeniu przepisów porządkowych w miejscach publicznych, zakłócaniu spokoju nocnego, niszczeniu ogrodów oraz wykroczenia popełnione w stanie upojenia alkoholowego. Z. Łukaszkiewicz, Orzecznictwo karno-administracyjne w walce z chuligaństwem, [w:] Chuligaństwo, red. J. Sawicki, Warszawa 1956, s. 134.

${ }^{80}$ Ibidem.

${ }^{81}$ Jako przykład mogą posłużyć dane statystyczne dotyczące Kolegium Orzekającego przy Prezydium Miejskiej Rady Narodowej w Poznaniu, które w 1955 r. karę pracy poprawczej w wymiarze do 6 dni zastosowało wobec 2478 osób, powyżej 6 dni - do 415 osób, natomiast w wymiarze powyżej miesiąca wobec 175 osób. T. Cyprian, Niektóre formy i przyczyny chuligaństwa, [w:] Chuligaństwo..., op. cit., S. 191.

82 Przykładowo w 1954 r. w referacie karno-administracyjnym Dzielnicowej Rady Narodowej Warszawa-Śródmieście 58\% orzeczeń karzących chuliganów pracą poprawczą nie zostało wykonanych. J. Rawicz, Przeciw chuligaństwu, „Trybuna Ludu” z 29 grudnia 1954 r.

${ }^{83}$ W propagandowej broszurze wydanej w 1957 r. celem popularyzacji kolegiów karno-administracyjnych podano przykład chuligana ukaranego karą pracy poprawczej, która to kara z powodu zaniedbań ze strony prezydium rady narodowej nie została wykonana i uległa przedawnieniu. W konsekwencji „chuligan taki dochodzi do przekonania, że może sobie hulać bezkarnie, gdyż nawet jeżeli kolegium wymierzy mu karę, to i tak nie będzie ona wykonana”. J. Chełmoński, J. Malinowski, Otrzymałem wezwanie..., op. cit., s. 60 . 
jewództwa łódzkiego, gdzie w 1955 r. „nieterminowe ściąganie orzeczonych kar, zbyt niski ich wymiar, względnie dopuszczanie się przedawnień [...] prowadzą do rozzuchwalania się sprawców wykroczeń, do dalszego popełniania wykroczeń zarówno przez obwinionego, jak i przez środowisko, w którym on przebywa" ${ }^{44}$. Jako przykład podano przypadek Mariana Kurzyny, który za wykroczenia chuligańskie został trzykrotnie ukarany karą pracy poprawczej w wymiarze 6 dni, lecz skutecznie uchylał się od podjęcia wyznaczonej pracy. „Mechaniczne wymierzanie niskich kar chuliganowi-recydywiście” skutkowało tym, „że obwiniony do tego stopnia się rozzuchwalił, że w dniu 19 października 1955 r. pobił funkcjonariusza Milicji Obywatelskiej i dopiero wówczas zdecydowano się sprawę przekazać do dyspozycji prokuratora" ${ }^{85}$.

\section{Kara pracy poprawczej po 1956 r.}

Wraz z pojawianiem się symptomów procesu odwilży, którego zwieńczenie stanowiły przemiany społeczno-polityczne roku 1956, narastała krytyka niektórych aspektów socjalistycznego modelu orzecznictwa karno-administracyjnego. Zarzuty dotyczyły zwłaszcza stępienia represyjnego ostrza stosowanych kar wskutek rezygnacji z kary aresztu i przykładania zbyt dużej wagi do wychowawczej roli kary pracy poprawczej. Wskazywano przy tym na rosnące zaległości $\mathrm{w}$ realizacji orzeczonych kar i masowe uchylanie się od ich wykonania, przy czym uwagi te dotyczyły w szczególności kar za wykroczenia o charakterze chuligańskim. Falę krytycznych wypowiedzi zapoczątkował Z. Łukaszkiewicz, który pod koniec 1955 r. odważył się oficjalnie stwierdzić, iż „kara pracy poprawczej wskutek jej wadliwego wykonania nie spełniła pokładanych w niej nadziei, szczególnie w walce z chuligaństwem, wymagającej z istoty rzeczy zdecydowanej postawy, nie przyniosła oczekiwanych rezultatów" ${ }^{\prime 6}$. Dla przeciwwagi podkreślano skuteczność zastępczej kary aresztu w sprawach o niewykonanie dostaw obowiązkowych, gdyż ,istotnym czynnikiem, który wpływał na wywiązywanie się z obowiązku dostaw, było szerokie stosowanie środków karnych" ${ }^{87}$. Niepowodzenie wychowawczej koncepcji orzecznictwa karno-administracyjnego, a zwłaszcza fiasko kary pracy poprawczej, która nie zdała egzaminu w polskich warunkach społecznych, zmusiły władze do reformy dotychczasowego mode$\mathrm{lu}^{88}$. Reforma miała stanowić element prac kodyfikacyjnych $\mathrm{w}$ zakresie prawa wykroczeń i postępowania karno-administracyjnego. W wykonaniu tych zało-

\footnotetext{
${ }^{84}$ Nasze trudności..., op. cit., s. 14.

${ }^{85}$ Ibidem, s. 15.

${ }^{86}$ Z. Łukaszkiewicz, Orzecznictwo karno-administracyjne..., s. 134.

${ }^{87}$ A. Gubiński, Ewolucja stosowanych przez kolegia środków karnych..., s. 29.

${ }^{88}$ A. Marek, Problemy reformy..., s. 196.
} 
żeń MSW opracowało w drugiej połowie 1956 r. projekt skodyfikowanego prawa karno-administracyjnego ${ }^{89}$.

Projekt utrzymywał wychowawczą koncepcję orzecznictwa karno-administracyjnego przy istotnych zmianach w dotychczasowym systemie kar. Zrezygnowano z zastępczej kary aresztu w sprawach o niewykonanie dostaw obowiązkowych oraz „z powodów zasadniczych” odstąpiono od kary pracy poprawczej. Obok grzywny funkcję kary głównej o szerokim zakresie stosowania miała pełnić kara nagany publicznej, której wprowadzenie „ma na celu wzmocnienie środków wychowawczych i zastąpienie środków represji materialnej środkami oddziaływania społecznego". Łagodniejszą formę nagany stanowiło upomnienie. Podczas zebrania Kolegium MSW w lutym $1957 \mathrm{r}$. Chmielewski przedstawił wspomniane wcześniej „zasadnicze powody”, dla których zrezygnowano z kary pracy poprawczej. Pierwszy z nich dotyczył niezgodności tej kary z konstytucyjnym pojęciem pracy, gdyż według ustawy zasadniczej praca była prawem, obowiązkiem i sprawą honoru każdego obywatela. Kara pracy poprawczej stosowana jako narzędzie represji stała w sprzeczności z konstytucyjną rangą pracy jako zaszczytnego obowiązku ${ }^{90}$. Drugi powód to zawiedzione nadzieje pokładane w tej karze, gdyż „W założeniu swym praca poprawcza miała być karą najcięższą, w praktyce jednak często - wobec formalistycznego jej wykonywania - była co najwyżej równie uciążliwa jak kara grzywny, a nawet mniej (gdyż praktycznie praca poprawcza równała się grzywnie rozłożonej na raty)"'91. Rezygnacja twórców projektu z kary pracy poprawczej nie oznaczała krytycznej oceny wszystkich jej aspektów, gdyż dostrzeżono jej pozytywne skutki w postaci wychowawczego oddziaływania na ukaranego w przypadku podania orzeczenia do publicznej wiadomości załogi zakładu pracy. „Pręgierz opinii publicznej, potępienie ze strony najbliższego otoczenia ukaranego" przyjęto za podstawę wychowawczego oddziaływania najsurowszej według twórców projektu kary - nagany publicznej ${ }^{92}$.

Opracowany przez MSW w 1956 r. projekt prawa karno-administracyjnego nie został wprowadzony w życie, gdyż kodyfikując prawo wykroczeń zwracano baczną uwagę na przebieg prac nad projektem kodeksu karnego. Przyjęto bowiem, iż pomimo swojej odrębności prawo karno-administracyjne uzupełnia przepisy prawa karnego, pełniąc wraz z nim funkcje ochrony prawidłowości toku

${ }^{89}$ Projekt został opracowany w latach 1956-1957 przez Biuro Nadzoru nad Orzecznictwem Karno-Administracyjnym MSW, którym kierował Henryk Chmielewski. Zagadnienia dotyczące zakresu i metody prac nad projektem części szczególnej prawa o wykroczeniach - opracowany 3 czerwca 1960 roku AAN MS 692, s. 6.

${ }^{90}$ J. Jasiński, O projekcie prawa karno-administracyjnego, „Nowe Prawo” (dalej: NP) 1957, nr 5, s. 84.

${ }^{91}$ Protokół z posiedzenia Kolegium MSW z dnia 9 lutego 1957 r. Instytut Pamięci Narodowej Oddział w Warszawie, Biuro Udostępniania i Archiwizacji Dokumentów, zespół akt MSW II, sygnatura teczki 4 , s. 231.

${ }^{92}$ Ibidem, s. 232. 
życia społecznego. W związku z tym wstrzymano się z kodyfikacją materialnego prawa wykroczeń do momentu ukończenia prac nad nowym kodeksem karnym, co nastąpiło dopiero $\mathrm{w}$ drugiej połowie lat sześćdziesiątych. Zamiast całościowej kodyfikacji zdecydowano się na doraźną nowelizację ustawy z 15 grudnia 1951 roku, której celem było dostosowanie opartego na stalinowskich założeniach orzecznictwa karno-administracyjnego do realiów okresu gomułkowskiego. Chodziło zwłaszcza o szeroko nagłaśniany problem zwalczania chuligaństwa, skutkiem czego niektóre rozwiązania nowelizacji „określiła wspólna uchwała Komisji Wymiaru Sprawiedliwości i Komisji Spraw Wewnętrznych Sejmu z dnia 5 grudnia $1957 \mathrm{r}$. w przedmiocie walk z chuligaństwem" ${ }^{93}$. Zawarty w tej uchwale postulat zaostrzenia represji wobec chuliganów oznaczał rezygnację czynników partyjno-rządowych z kary pracy poprawczej, gdyż nie była ona w stanie skutecznie przeciwdziałać popełnianiu wykroczeń o charakterze chuligańskim. Przyjęta 22 maja 1958 r. ustawa o zaostrzeniu odpowiedzialności karnej za chuligaństwo ${ }^{94}$ wprowadzała istotne zmiany w orzecznictwie karnoadministracyjnym. Wzmocniono jego represyjność przez wprowadzenie kary aresztu stosowanej wobec sprawców wykroczeń o charakterze chuligańskim, przy czym chuligański charakter czynu stanowił okoliczność wpływającą na zaostrzenie kary ${ }^{95}$. Ustawa antychuligańska znosiła możliwość orzeczenia kary pracy poprawczej ${ }^{96}$, co w praktyce oznaczało znaczne ograniczenie zakresu jej stosowania ${ }^{97}$. W tym miejscu warto nadmienić, iż pierwszy krok w kierunku rezygnacji z kary pracy poprawczej stanowiła ustawa z 13 lipca 1957 r. o zwalczaniu spekulacji $i^{98}$, która w sprawach o wykroczenia w niej uregulowane przewidywała grzywnę ${ }^{99}$.

Rozwiązania przyjęte $\mathrm{w}$ ustawie antychuligańskiej poprzedzały zasadnicze zmiany całokształtu orzekania w sprawach o wykroczenia, planowane w noweli do ustawy z 15 grudnia $1951 \mathrm{r}^{100}$ Przygotowując się do całkowitego zniesienia kary pracy poprawczej, MSW pod koniec 1957 r. zaleciło prezydiom rad narodowych zamieszczenie opinii na temat tej kary w kwartalnych sprawozdaniach z przebiegu orzecznictwa karno-administracyjnego na danym terenie. Wszystkie bez wyjątku prezydia „postulowały zniesienie kary pracy poprawczej, która ich zdaniem nie dawała pożądanych efektów, a sztuczne jej utrzymywanie wy-

${ }^{93}$ Uzasadnienie projektu zmiany ustawy o orzecznictwie karno-administracyjnym z 1958. r., AAN MS 2009, s. 271.

${ }^{94}$ Dz. U. Nr 34, poz. 152.

${ }^{95}$ Przeciw chuligaństwu, „Poradnik dla Kolegiów Orzekających” 1958, nr 4, s. 2.

${ }^{96}$ Nowe, poważne zadania, „Poradnik dla Kolegiów Orzekających” 1958, nr 3, s. 2-5.

${ }^{97}$ Sprawozdanie stenograficzne z 27 posiedzenia IV sesji Sejmu PRL II kadencji, łam 93.

${ }^{98}$ Ustawa z dnia 13 lipca 1957 r. o zwalczaniu spekulacji i ochronie interesów nabywców oraz producentów w obrocie handlowym (Dz. U. Nr 39, poz. 171).

${ }^{99}$ J. Warecki, Odpowiadamy na pytania, „Poradnik dla Kolegiów Orzekających” 1957, nr 5, s. 37.

100 Nowe, poważne zadania..., s. 5. 
magało nieproporcjonalnego nakładu sił i środków”. Z kolei ustosunkowując się do projektu nowelizacji ustawy z 15 grudnia 1951 r. wszystkie prezydia opowiedziały się „przeciwko pozostawieniu w orzecznictwie kolegiów kary pracy poprawczej” ${ }^{101}$.

Zniesieniu kary pracy poprawczej sprzeciwiało się jedynie Ministerstwo Sprawiedliwości ${ }^{102}$, postulując utrzymanie tej kary w zmodyfikowanej postaci wobec osób niezatrudnionych $\mathrm{w}$ sektorze uspołecznionym. Zdaniem Ministerstwa, w celu objęcia karą pracy poprawczej osób niepracujących należałoby „znaleźć pewne możliwości uruchomienia robót melioracyjnych, porządkowych, oczyszczania miast i osiedli, reperacji dróg, regulacji rzek". Powoływano się także na fakt, iż uchylenie kary pracy poprawczej pociągałoby za sobą konieczność jej zastąpienia karą aresztu bądź grzywną. Przy dużej liczbie spraw rozpoznawanych przez kolegia, częste orzekanie aresztu prowadziłoby do powstania kłopotów z wykonaniem tej kary, takich jak brak zakładów karnych, uciążliwość i kosztowność wykonania krótkotrwałych, z reguły 7-14 dniowych kar. Realizacja kar grzywny w stosunku do osób niepracujących sprowadzałaby się do orzekania kary aresztu zastępczego. W konkluzji swoich wywodów Ministerstwo Sprawiedliwości stwierdziło, że „W obecnym stadium zniesienie kary pracy poprawczej nie jest właściwe"103.

Zasadność utrzymania tej kary miała także wynikać z faktu, że przewidział ją opracowany w 1956 r. projekt kodeksu karnego w odniesieniu do występków mniejszej wagi. Zgodnie z art. 26 projektu karę pracy poprawczej odbywa się na wolności w miejscu swojego zatrudnienia lub w innym miejscu przez potrącenie od $10 \%$ do $25 \%$ wynagrodzenia z pracę.

Celem poparcia swojego stanowiska Ministerstwo Sprawiedliwości przywoływało przykład „Związku Radzieckiego i szeregu krajów demokracji ludowej, w których kara taka jest stosowana i jej stosowanie nie nasuwa szczególnych trudności” ${ }^{104}$. Siła oddziaływania tego argumentu w czasach „polskiej drogi do socjalizmu" była nieporównywalnie niższa niż w okresie stalinowskim, skutkiem czego protesty Ministerstwa Sprawiedliwości nie wpłynęły na zmianę kierunku prac nad reformą prawa orzecznictwa karno-administracyjnego.

Przyjęta 2 grudnia 1958 r. nowelizacja ${ }^{105}$ miała na celu usunięcie mankamentów stwierdzonych w dotychczasowej praktyce orzecznictwa karno-administracyjnego. Twórcy nowelizacji wskazywali zwłaszcza na niski poziom pracy

101 Notatka w sprawie kary pracy..., s. 9.

102 Wyrazem tego były pisma skierowane do ministra spraw wewnętrznych w lutym i maju 1958 roku. Notatka Ministerstwa Sprawiedliwości..., op. cit., s. 3.

103 Uzasadnienie projektu zmiany ustawy..., s. 180.

104 Notatka Ministerstwa Sprawiedliwości..., op. cit., s. 3.

105 Ustawa z dnia 2 grudnia 1958 r. o zmianie ustawy z dnia 15 grudnia 1951 r. o orzecznictwie karno-administracyjnym (Dz. U. Nr 77, poz. 396). 
kolegiów na najniższych szczeblach podziału terytorialnego ${ }^{106}$ oraz nieskuteczność stosowanych przez kolegia środków karnych. W związku z tym postulowano „urealnienie sankcji karnych stosowanych przez kolegia” przez „danie im bardziej skutecznego oręża”. Stwierdzenie to oznaczało rezygnację z kary pracy poprawczej, której mankamenty wskazała referująca projekt nowelizacji poseł sprawozdawca Zofia Stypułkowska. Szczególnej krytyce poddała zasadność stosowania tej kary wobec osób niezatrudnionych w sektorze uspołecznionym, takich jak „elementy chuligańskie”, włóczędzy i bumelanci, w warunkach powszechnego dążenia do zwiększenia wydajności pracy i wartości pracownika. Rezygnując z pracy poprawczej, nowelizacja przywróciła karę aresztu, co de facto oznaczało przyznanie się do fiaska koncepcji wychowawczej orzecznictwa karno-administracyjnego. Reliktem tej koncepcji pozostała kara wprowadzona przez nowelizację kara nagany, którą orzekano w przypadku małej szkodliwości społecznej czynu.

Kara aresztu była przewidziana za wykroczenia określone w ustawie antychuligańskiej oraz wykroczenia enumeratywnie wyliczone w ustawie nowelizującej. W pozostałych przypadkach kolegia orzekały grzywnę, która wyszła zwycięsko z pojedynku między karami aresztu i pracy poprawczej, oficjalnie awansując do rangi podstawowego środka karnego. Dotychczasową nieskuteczność tej kary w postaci niskiej ściągalności miała zlikwidować wprowadzona przez nowelizację zastępcza kara aresztu. Kolegium miało prawo do ustalenia w orzeczeniu o ukaraniu, że w przypadku nieuiszczenia w terminie grzywny ulegnie ona zamianie na areszt w proporcji odpowiedniej do wysokości grzywny ${ }^{107}$.

Zaostrzenie represyjności orzecznictwa karno-administracyjnego skutkowało znaczną poprawą skuteczności orzeczonych kar grzywny, co zostało odnotowane przez MSW w notatce z 1960 r. Zawarto w niej stwierdzenie, iż „sytuacja uległa radykalnej zmianie po wprowadzeniu noweli z 1958 r. [...] wprowadzającej grzywnę z ewentualną zamianą na areszt". Według posiadanych przez MSW informacji w 1959 r., „około 90\% kar zostało wykonanych lub pozostaje w trakcie wykonania, z tego zaś $72 \%$ jest całkowicie zrealizowanych". Podkreślano przy tym skuteczność zastępczej kary aresztu, gdyż „na około 111 tys. ukaranych tą karą 63000 od razu uiściło grzywny, pozostałe 40000 też w zasadzie karę wykonało". Zasadnicza kara aresztu była stosowana w sposób umiarkowany, gdyż „miesięcznie odbywało karę aresztu przeciętnie 1574 osoby, co w porównaniu z około 1 milionem spraw, które w tym roku rozstrzygnęły kolegia, jest liczbą niedużą"108.

106 Nowelizacja ustawy z 15 grudnia 1951 r. znosiła kolegia funkcjonujące dotychczas przy prezydiach gromadzkich rad narodowych. M. Sikorowa, Uwagi o ustawie $z$ dnia 2 XII 1958 r. w sprawie orzecznictwa karno-administracyjnego, „Biuletyn Generalnej Prokuratury” 1958, nr 11-12, s. 37-38.

107 Sprawozdanie stenograficzne z 27 posiedzenia ..., łam 93.

108 Notatka w sprawie kary pracy..., s. 11. 
Rezygnacja $\mathrm{z}$ kary pracy poprawczej spotkała się z aprobatą przedstawicieli doktryny, którzy nie negując jej walorów wychowawczych, eksponowali trudności wynikłe z praktycznego stosowania tej kary. Podkreślając zasadność tego posunięcia, E. Iserzon przywołał przykład Związku Radzieckiego, „gdzie stosunek do kary pracy poprawczej uległ ostatnio zmianie i instytucja ta spotkała się z negatywną oceną, tak że kara ta ostatnio nie jest stosowana” ${ }^{\prime 109}$. Z kolei J. Bafia, wykazując zrozumienie dla powodów rezygnacji z kary pracy poprawczej, wyrażał niezadowolenie z częściowego przywrócenia kary aresztu i określił takie rozwiązanie jako nie najlepsze. Jego zdaniem oznaczało to zbyt daleko idący odwrót od wychowawczej koncepcji orzecznictwa karno-administracyjnego na rzecz dominacji kary grzywny pociągającej za sobą dolegliwość natury ekonomicznej ${ }^{110}$.

Problem zasadności wprowadzenia w polskich realiach kary pracy poprawczej powrócił wraz z podjęciem na początku lat sześćdziesiątych prac nad kodyfikacją prawa karno-administracyjnego. Prace były prowadzone przez specjalnie w tym celu powołaną komisję, której członkowie byli delegowani przez ministrów sprawiedliwości i spraw wewnętrznych. Nawiązując do stanowiska prezentowanego w trakcie prac nad projektem nowelizacji ustawy z 15 grudnia 1951 roku, Ministerstwo Sprawiedliwości wskazywało na konieczność restytucji kary pracy poprawczej celem uzupełnienia istniejącego systemu środków karnych. Operująca sankcją pośrednią między aresztem i grzywną kara pracy poprawczej byłaby orzekana wobec przypadkowych sprawców wykroczeń popełnianych $\mathrm{z}$ winy nieumyślnej. Stosowanie wobec sprawców drobnych przewienień kary aresztu zastępczego $\mathrm{w}$ razie niezapłacenia przez nich grzywny „może nie tylko nie wypełnić właściwej wychowawczej roli, lecz przeciwnie - może wypaczyć człowieka uczciwego". Tego rodzaju ujemnych skutków miała być pozbawiona kara pracy poprawczej jako niepodlegająca zamianie na areszt. Dotkliwość kary pracy poprawczej nie ograniczałaby się do potrącenia części miesięcznego wynagrodzenia, gdyby jej orzekanie połączyć z dodatkowymi konsekwencjami. Konsekwencje te miałyby postać obowiązkowego podania wyroku skazującego do wiadomości załogi zakładu pracy ukaranego, zawieszenia na czas wykonywania kary wypłaty wszelkich dodatków do wynagrodzenia, czy też zakazu awansowania ukaranego. Kara pracy poprawczej powinna być egzekwowana w drodze potrącenia od $15 \%$ do $25 \%$ wynagrodzenia za pracę lub przez wykonywanie prac o charakterze porządkowym ${ }^{111}$. Zdaniem Ministerstwa Sprawiedliwości wskazane byłoby przedłużenie czasu trwania pracy poprawczej do 1 roku $^{112}$.

109 E. Iserzon, Reforma orzecznictwa karno-administracyjnego, PiP 1959, nr 8-9, s. 261.

110 J. Bafia, Zmiany w ustawie o orzecznictwie karno-administracyjnym, NP 1959, nr 1, s. 34.

111 Prace te powinny mieć formę robót publicznych przeprowadzanych na wolności przy budowie dróg, regulacji rzek, uprzątaniu miast. Materiały dotyczace części ogólnej projektu praw o wykroczeniach przygotowane na I plenarne posiedzenie Komisji do opracowania jednolitych przepisów o postępowaniu karno-administracyjnym w dniach 6 i 7 czerwca 1960 r., AAN MS 1963, s.93.

112 Notatka Ministerstwa Sprawiedliwości..., s. 5. 
Opracowany przez wspomnianą komisję w 1961 r. projekt prawa o wykroczeniach nie uwzględniał powyższych postulatów, gdyż restytucji kary pracy poprawczej zdecydowanie sprzeciwiało się MSW, pomne negatywnych doświadczeń z przeszłości. Ograniczenie katalogu środków karnych do aresztu administracyjnego, nagany publicznej i grzywny ${ }^{113}$ poddał w wątpliwość na łamach „Nowego Prawa" reprezentujący Ministerstwo Sprawiedliwości Leo Hochberg. Jego zdaniem kara pracy poprawczej pod warunkiem należytego uregulowania jej sposobu wykonania powinna zostać przywrócona, gdyż „doświadczenie innych krajów obozu socjalistycznego przemawia za wprowadzeniem takiej kary"114.

Ostateczną redakcję projektu prawa o wykroczeniach pozostawiono bez nadania jej dalszego biegu w 1963 r., ponieważ opracowywany równolegle projekt kodeksu karnego nie zyskał akceptacji ówczesnych władz. Zaawansowanie prac nad kolejnym projektem kodeksu karnego postawiło w 1967 r. na porządku dziennym ponowne przygotowanie projektu kodyfikacji prawa wykroczeń. Ze względu na istniejące między tymi aktami prawnymi powiązania zamierzano jednocześnie wprowadzić je w życie. Opierając się na rezultatach prac podjętych na początku lat sześćdziesiątych, ogłoszono projekt prawa o wykroczeniach, który stał się podstawą późniejszej kodyfikacji tego prawa w $1971 \mathrm{r}^{115}$. Projekt utrzymał dotychczasowy system środków karnych, nie wprowadzając występującej w projekcie kodeksu karnego tzw. kary ograniczenia wolności. Argumentowano to tym, że kara ograniczenia wolności orzekana przez kolegia na okres co najwyżej 3 miesięcy byłaby, przy niewspółmiernie dużych trudnościach wykonania, nieefektywna. Ponadto stwierdzono, że kara ta zbliżona jest do „znanej już w praktyce kolegiów kary pracy poprawczej, która w praktyce z wielu względów nie zdała egzaminu i zrezygnowano z niej w 1958 r."116

Projekt prawa o wykroczeniach został poddany w 1967 r. pod dyskusję środowiskową. Na podstawie jej wyników połączone kolegium ministerstw sprawiedliwości i spraw wewnętrznych opracowało w końcu 1968 r. ostateczną wersję projektu ${ }^{117}$. Różniła się ona od pierwowzoru, przy czym wprowadzone zmiany dotyczyły w szczególności rozszerzenia katalogu środków karnych. Wzorem kodeksu karnego do projektu prawa o wykroczeniach wprowadzono odrzuconą początkowo karę ograniczenia wolności, która wykazywała znaczne podobieństwo do kary pracy poprawczej. Podobieństwo polegało na wykonywaniu kary bez pozbawienia skazanego wolności oraz na zobowiązaniu ukaranego do podjęcia pracy wskazanej przez organ orzekający. W przypadku osoby zatrudnionej w sektorze uspołecznionym możliwe było orzeczenie potrącenia od 10\% do $25 \%$

\footnotetext{
113 Z prac nad projektem nowego prawa o wykroczeniach, ZK-A 1961, nr 2, s. 19.

114 L. Hochberg, Kodyfikacja przepisów o wykroczeniach, NP 1961, nr 9, s. 1077.

115 D. Egierska-Pakuła, Zmiany w projekcie prawa o wykroczeniach, ZK-A 1969, nr 1, s. 13-15.

116 D. Egierska-Pakuła, Projekt prawa o wykroczeniach, ZK-A 1967, nr 5, s. 24.

117 D. Egierska-Pakuła, Zmiany w projekcie prawa..., s. 13.
} 
wartości wynagrodzenia ${ }^{118}$. Decydując się na wprowadzenie kary ograniczenia wolności, zamieszczono w projekcie kodeku wykroczeń rozwiązania służące zagwarantowaniu skutecznego wykonywania orzeczeń. Analizując trafnie przyczyny trudności związanych z praktycznym stosowaniem kary pracy poprawczej, przyjęto wyższą dolną granicę kary ograniczenia wolności w wymiarze jednego miesiąca. Na ukaranego nałożono dodatkowe obowiązki w postaci zakazu zmiany miejsca stałego pobytu w okresie odbywania kary i udzielania wyjaśnień dotyczących przebiegu jej wykonania. W przypadku orzeczenia potrącenia $\mathrm{z}$ wynagrodzenia sprawca ponosił dodatkowe konsekwencje, gdyż w okresie odbywania kary nie mógł rozwiązać stosunku pracy ani zostać przeniesiony na wyższe stanowisko. Wychowawcze walory kary ograniczenia wolności, polegające na wdrażaniu ukaranego do pracy, wzmacniała możliwość zobowiązania ukaranego do naprawienia szkody wyrządzonej wykroczeniem lub do przeproszenia pokrzywdzonego. Uchylanie się od wykonania kary ograniczenia wolności zabezpieczono przez zamianę tej kary na grzywnę. Jeżeli egzekucja grzywny okazałaby się nieskuteczna, to w grę wchodziła zastępcza kara aresztu ${ }^{119}$.

Rozwiązania projektu w zakresie środków karnych przejmował uchwalony 20 maja 1971 r. kodeks wykroczeńn ${ }^{120}$. Przewidywał ograniczenie wolności jako sankcję alternatywną, występującą przeważnie z karą aresztu i grzywną, a czasami łącznie z samą grzywną jako karę najsurowszą. Zdaniem J. Bafii, „kara ograniczenia wolności weszła do prawa o wykroczeniach przez szeroko otwartą bramę, powinna więc odegrać istotną rolę $\mathrm{w}$ procesie karania i wychowywania przez pracę i środowisko zakładu pracy"121. Pomimo zmian systemowych związanych z upadkiem systemu komunistycznego, kara ograniczenia wolności praktycznie $\mathrm{w}$ niezmienionej postaci funkcjonuje do dnia dzisiejszego w polskim prawie wykroczeń.

\section{Wnioski}

Reforma orzecznictwa karno-administracyjnego w grudniu 1951 r. stanowiła jeden z elementów procesu sowietyzacji prawa Polski Ludowej, czyli mechanicznego przenoszenia na polski grunt rozwiązań radzieckich. U podstaw wprowadzenia socjalistycznego modelu orzecznictwa w sprawach o wykroczenia legła teoria o wychowawczej roli kary administracyjnej jako instrumentu kształtowania postaw obywatelskich w kierunku pożądanym przez władzę. Przysługujące administracji prawo karania za wykroczenia było wykorzystywane

118 A. Gubiński, Niektóre zagadnienia kodyfikacji prawa o wykroczeniach, PiP 1968, nr 2, s. 222-223 .

119 D. Egierska, J. Smereczyński, Projekt prawa o wykroczeniach, NP 1969, nr 4, s. 526-527.

120 Dz. U. Nr 12, poz. 114.

121 J. Bafia, Kodyfikacja prawa o wykroczeniach, PiP 1971, nr 10, s. 516. 
w celu wspierania procesu wprowadzania systemu gospodarki planowej, w którym to procesie aparat administracji pełnił aktywną rolę. Stosowanie represji karno-administracyjnej miało na celu nie tylko dolegliwość materialną, jak to miało miejsce w przypadku kar aresztu i grzywny orzekanych na podstawie przepisów pochodzących z okresu międzywojennego. Kara administracyjna miała pełnić nieznaną dotychczasowym rozwiązaniom funkcję prewencji szczególnej, polegającą na wdrażaniu karanego do przestrzegania porządku prawnego i sumiennego wykonywania obowiązków na rzecz państwa. Stępienie represyjnego ostrza orzecznictwa karno-administracyjnego na rzecz oddziaływania wychowawczego oparto na nierealnym założeniu o wzroście świadomości społeczeństwa wraz z postępami budownictwa socjalistycznego. Kary administracyjne miały pomóc ukaranemu w pozbyciu się nawyków nieprzystających do wzorca człowieka socjalistycznego, od którego wymagano aktywnej postawy w procesie budowy nowego ustroju. Formą aktywności ukaranego miała być praca społecznie użyteczna, której rezultaty częściowo przypadały państwu jako rekompensata za niewłaściwą postawę osoby skazanej wobec zadań budownictwa socjalistycznego.

Wychowawczą funkcję orzecznictwa karno-administracyjnego najpełniej oddawała kara pracy poprawczej, której wprowadzenie „,pomyślane było niewątpliwie jako realizacja nowego stosunku do sprawcy wykroczenia, jako zastąpienie elementów represyjnych kary elementami wychowawczymi”"122. Kara ta miała łączyć w sobie typową dla grzywny dolegliwość materialną z ograniczeniem wolności wykonywania pracy, stanowiąc coś pośredniego między karą pozbawienia wolności a karą grzywny ${ }^{123}$. Eksponowanie czynników natury wychowawczej służyło podkreśleniu powagi i surowości kary pracy poprawczej na tle funkcjonującej także w socjalistycznym modelu orzecznictwa karno-administracyjnego grzywny. Przyznanie karze pracy poprawczej pierwszoplanowej roli w systemie środków karnych stosowanych przez kolegia wynikało z „oddziaływania opinii otoczenia sprawcy czynu, potępienia towarzyszy pracy”"124.

Z karą pracy poprawczej wiązano duże nadzieje, tym bardziej że dotychczas stosowane środki represji wskutek trudności z wykonywaniem kar aresztu w ograniczonym stopniu spełniały zadania prewencyjne. Sposób realizacji orzeczeń o ukaraniu pracą poprawczą w warunkach gospodarki planowej, gdzie obowiązywał przymus pracy i zapotrzebowanie na darmową siłę roboczą wydawał się być optymalny. Praktyka w sposób brutalny zweryfikowała te oczekiwania, gdyż zakłady pracy lekceważąco podchodziły do egzekwowania kar nałożonych na swoich pracowników. Mechaniczne potrącanie części poborów ukaranego,

122 Z. Łukaszkiewicz, Orzecznictwo karno-administracyjne..., s. 134.

123 Notatka Ministerstwa Sprawiedliwości..., s. 2.

124 O pracy kolegiów orzekających..., s. 37. 
bez informowania współtowarzyszy pracy o fakcie popełnienia wykroczenia przez ich kolegę, sprowadzało pracę poprawczą do roli grzywny rozłożonej na raty. Jeszcze gorzej przedstawiała się realizacja tej kary w stosunku do osób niezatrudnionych w sektorze uspołecznionym, gdyż zakłady pracy broniły się przed przyjmowaniem niewykwalifikowanych pracowników sezonowych. Prowadziło to do faktycznej bezkarności wykroczeń popełnianych przez osoby z marginesu społecznego i rozwoju tzw. chuligaństwa, z którym tak zaciekle walczyła ekipa Gomułki.

Panujący w okresie stalinowskim klimat propagandy sukcesu powodował, że oficjalnie nie przyznawano się do niepowodzenia eksperymentu kary pracy poprawczej. Milczącym potwierdzeniem fiaska tego eksperymentu było wprowadzenie w $1953 \mathrm{r}$. zastępczej kary aresztu w sprawach o niewykonywanie dostaw obowiązkowych, co oznaczało rezygnację ze stosowania kary pracy poprawczej w kluczowych dla kolegiów sprawach na terenach wiejskich. Rok 1956 przynosi przyzwolenie władz gomułkowskich na rzeczową i krytyczną analizę okresu stalinowskiego, skutkiem czego zarówno czynniki rządowe, jak i doktryna poddają $\mathrm{w}$ wątpliwość sens dalszego utrzymania kary pracy poprawczej. Nieskuteczność tej kary w walce $\mathrm{z}$ wykroczeniami o charakterze chuligańskim przy jednoczesnym eksponowaniu sukcesu zastępczej kary aresztu w sprawach o niewykonanie dostaw obowiązkowych stanowiły zapowiedź zmiany charakteru orzecznictwa karno-administracyjnego. Powszechne domaganie się zaostrzenia kar wobec chuliganów współgrało z „twardym kursem” obranym przez ekipę Gomułki, która szybko wycofała się z liberalnej polityki ustępstw na rzecz społeczeństwa. Wynikiem tego był powrót do represyjnej koncepcji orzecznictwa karno-administracyjnego, wyrażający się w przywróceniu kary aresztu w przypadku wykroczeń o charakterze chuligańskim. Przyjęta w 1958 r. ustawa antychuligańska wyznaczała kierunek reformy orzecznictwa karno-administracyjnego, w którym potępiana kara pracy poprawczej nie miała racji bytu. Przeprowadzone w grudniu $1958 \mathrm{r}$. zmiany eliminowały tę karę z orzecznictwa karno-administracyjnego, $\mathrm{w}$ jej miejsce wprowadzały w ograniczonym zakresie karę aresztu. Posuniecie to było zgodne z oczekiwaniami władz lansujących politykę zdecydowanego zwalczania zjawiska chuligaństwa, jednak względy polityczno-propagandowe usunęły na dalszy plan dyskusję nad celowością utrzymania kary pracy poprawczej w zmodyfikowanej postaci. Przy wprowadzeniu odpowiednich gwarancji skutecznego wykonywania tej kary w postaci aresztu zastępczego nie było to rozwiązanie pozbawione racji bytu. Próbowało tego dowieść broniące idei kary poprawczej Ministerstwo Sprawiedliwości, lecz jego postulaty zostały uwzględnione dopiero w końcowej fazie prac nad kodyfikacją prawa wykroczeń. Przyjęty w 1971 r. kodeks wykroczeń przewiduje bardzo zbliżoną do kary pracy poprawczej karę ograniczenia wolności, która jest obecnie orzekana przez sądy grodzkie w sprawach o wykroczenia. 